\title{
POŠTA
}

TELEKOMUNIKÁCIE A

ELEKTRONICKY OBCHOD

\section{ANALÝZA VÝVOJA TRHU S INFORMAČNO - KOMUNIKAČNÝMI TECHNOLÓGIAMI A JEHO ŠTRUKTÚRA}

\section{Kremeňová Iveta*}

\section{Úvod}

Informačný systém a informačné technológie sa stali prostredníctvom systémovej integrácie integrálnou súčast'ou podnikových procesov a podnikových zdrojov a sú nástrojom efektívneho riadenia podniku. Do integrovaného informačného systému podniku by mali byt' systémovo začlenené všetky procesy, zdroje, služby a produkty, ktoré súvisia s úlohami informačného strediska a organizácie.

\section{Analýza svetového ICT trhu}

Informačno-komunikačný trh (ICT) je trh, na ktorom sa obchoduje s informačnými a komunikačnými technológiami. V podstate sú to dva trhy, ktoré spolu vel'mi súvisia, navzájom sa ovplyvňujú, a preto ich uvádzame pod spoločným názvom ICT.

Na nasledujúcom Grafe č. 1 je znázornený ICT-trh rozčlenený podl’a geografického hl'adiska. USA zaberajú $28 \%$ a Japonsko $14,3 \%$. Ako je možné vidiet' najväčšiu čast' predstavuje Európa, ktorej podiel je 33,6\% svetového trhu, čo predstavuje hodnotu 681,027 miliárd Euro. Celková hodnota ICT trhu je 2,027 biliónu Euro.

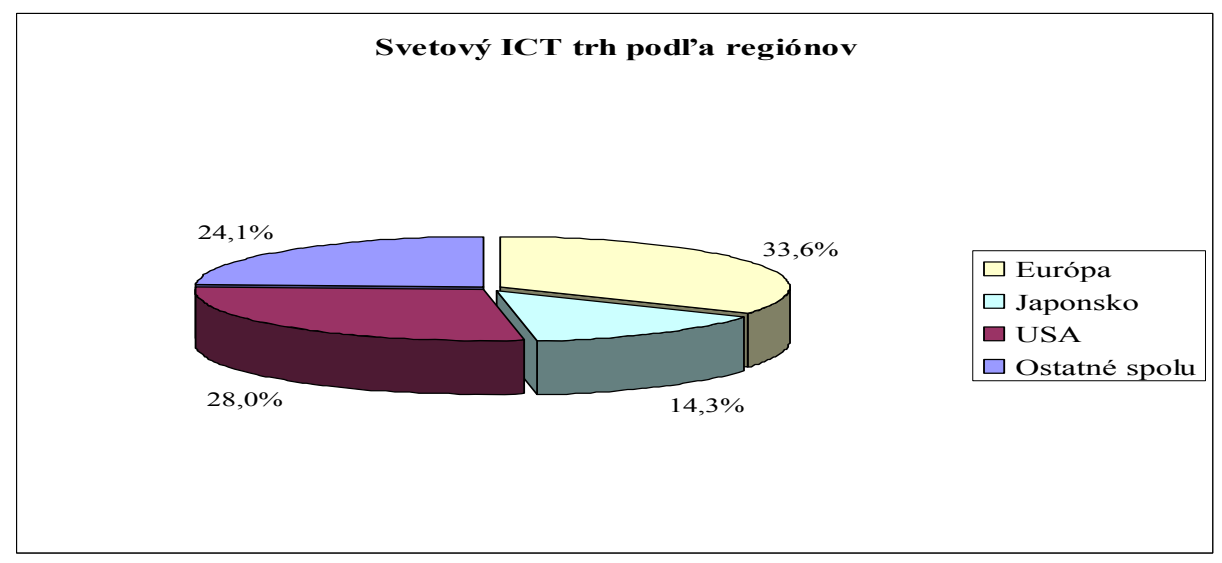

Graf 1 Svetový ICT trh podl'a regiónov (zdroj: http://www.eito.com/download/ EITO\%202006\%20-\%20ICT\%20market\%20March\%202006.pdf)

\footnotetext{
*Doc. Ing. Iveta Kremeňová, PhD., Katedra spojov, F-PEDAS, Žilinská univerzita v Žiline tel.:041/5133100, fax: 041/5655615

e-mail: Iveta.Kremenova@fpedas.utc.sk
} 
Tabul'ka 1 Svetový ICT trh podl'a regiónov zdroj:http://www.eito.com/download/EITO\%202006\%20\%20ICT\%20market\%20March\%202006.pdf)

\begin{tabular}{|c|c|}
\hline Názov subjektu & Podiel na trhu \\
\hline \hline Európa & $33,6 \%$ \\
\hline Japonsko & $14,3 \%$ \\
\hline USA & $28,0 \%$ \\
\hline Ostatné spolu & $24,1 \%$ \\
\hline
\end{tabular}

Trh informačných a komunikačných technológií zaznamenáva už tretí rok neustáleho rastu. Ak však rozdelíme trh podl'a geografického hl'adiska môžeme pozorovat' určité rozdiely. Ako je zrejmé vidiet' na Grafe 2, kým v USA je predpokladaný nárast trhu z 3,9\% v roku 2005 na 4\% pre rok 2007, v Európe je očakávaný pokles rastu z 3,7\% v roku 2005 na predpokladanú hodnotu 3\% v roku 2007. Pre Japonsko je prognózovaný ešte väčší pokles rastu z 2,1\% v roku 2005 na očakávané $1 \%$. Tieto rozdiely rastu sú spôsobené tým, že Japonsko je oproti väčším hráčom Európe a USA pomerne izolovaný a presýtený trh, a teda sa neočakávajú vel'ké percentá rastu trhu. V celosvetovom meradle nastáva pokles rastu ICT trhu. Jediným regiónom, v ktorom sa očakáva rast, je USA.

Tabul'ka 2 Nárasty svetového ICT trhu za roky 2005-2007 v \% (zdroj: http://www.eito.com/download/EITO\%202006\%20-\%20ICT\%20market\%20March\%202006.pdf)

\begin{tabular}{|c|c|c|c|}
\hline $\begin{array}{c}\text { Názov } \\
\text { subjektu }\end{array}$ & $\begin{array}{c}\text { Rast trhu za rok } \\
\mathbf{2 0 0 5}\end{array}$ & Rast trhu za rok 2006 & Rast trhu za rok 2007 \\
\hline \hline Európa & 3,7 & 3,2 & 3,0 \\
\hline Japonsko & 2,1 & 1,1 & 1,0 \\
\hline USA & 3,9 & 3,9 & 4,0 \\
\hline Ostatné spolu & 8,4 & 6,8 & 6,3 \\
\hline Svet & 4,6 & 4,0 & 3,8 \\
\hline
\end{tabular}

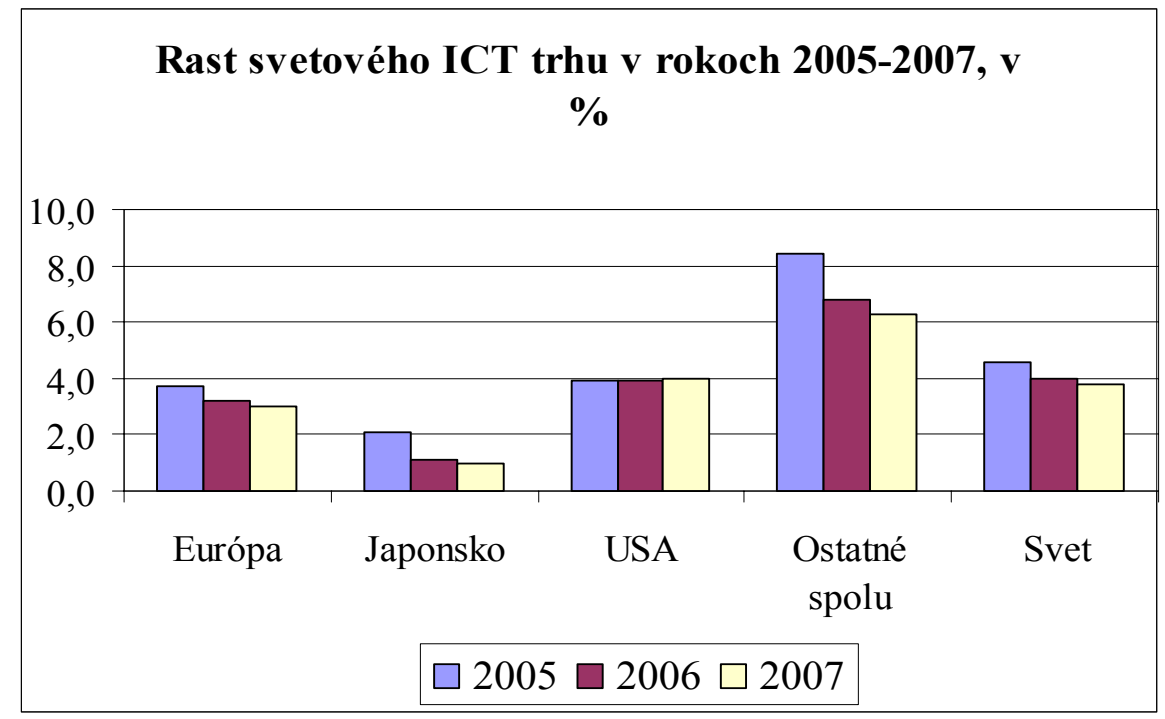

Graf 2 Nárasty svetového ICT trhu za roky 2005-2007, v \% (zdroj: http://www.eito.com/download/EITO\%202006\%20-\%20ICT\%20market\%20March\%202006.pdf) 
Podl'a European Information Technology Observatory (EITO) môžeme celkový ICT trh rozdelit' na dva trhy a to:

\section{0 trh IT}

o telekomunikačný trh

V Grafe č. 3 je prehl'adne znázornené porovnanie rastu týchto dvoch trhov v Európe po dobu desiatich rokov.

Tabul'ka 3 Rast Západoeurópskeho ICT trhu v rokoch 1997-2007, v \% (Zdroj:http://www.eito.com/download/EITO\%202006\%20\%20ICT\%20market\%20March\%202006.pdf)

\begin{tabular}{|c|c|c|c|c|c|c|c|c|c|c|c|}
\hline \multirow{2}{*}{ Trh } & \multicolumn{10}{|c|}{ v rokoch, v \% } \\
\cline { 2 - 12 } & 1997 & 1998 & 1999 & 2000 & 2001 & 2002 & 2003 & 2004 & 2005 & 2006 & 2007 \\
\hline \hline Telekomunikácie & 8,0 & 12,6 & 13,4 & 14,5 & 3,9 & 2,6 & 2,7 & 4,2 & 2,8 & 2,0 & 1,5 \\
\hline IT & 8,6 & 10,1 & 10,8 & 12,1 & 1,0 & $-3,4$ & $-1,9$ & 2,6 & 3,8 & 4,2 & 4,2 \\
\hline
\end{tabular}

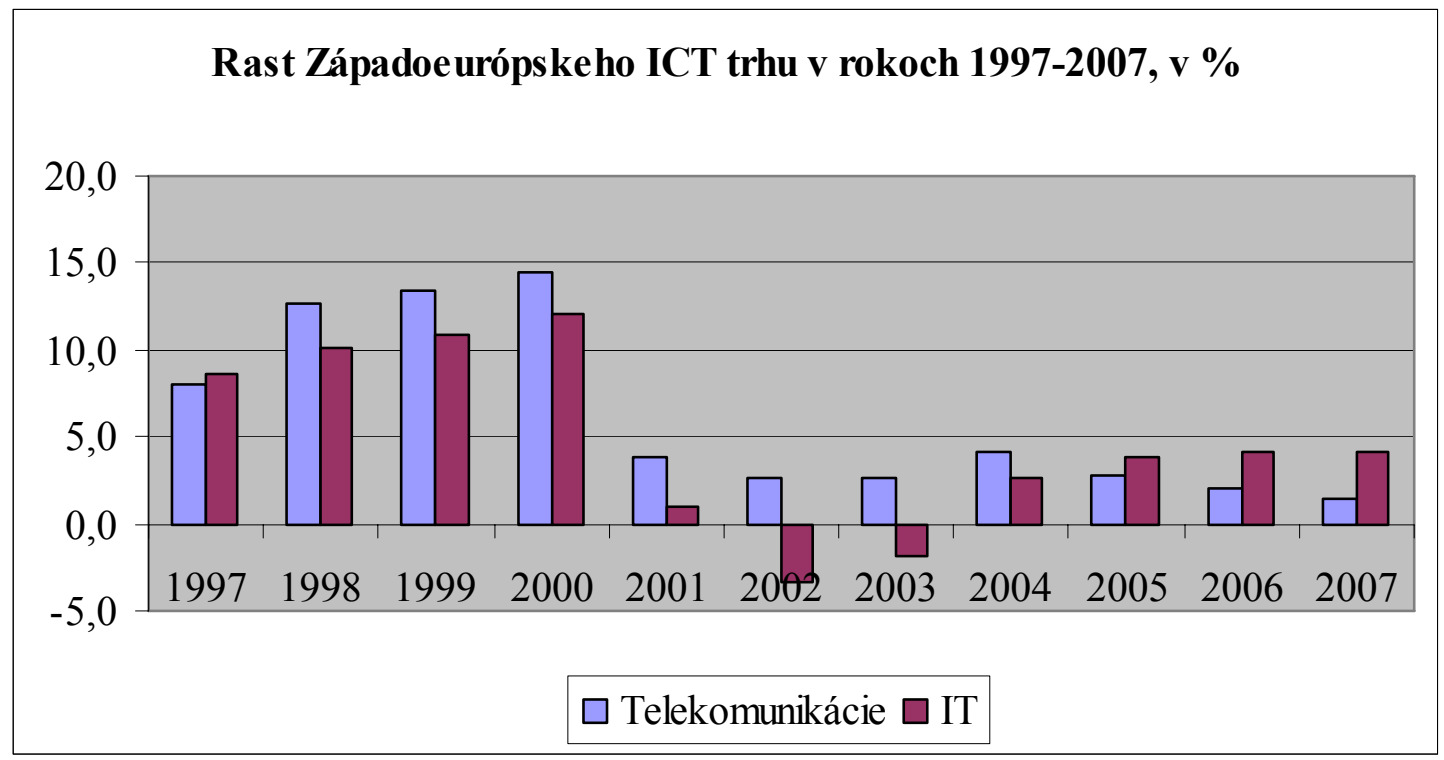

Graf 3 Rast Západoeurópskeho ICT trhu v rokoch 1997-2007, v \% (zdroj:http://www.eito.com/download/EITO\%202006\%20-\%20ICT\%20market\%20March\%202006.pdf)

Jasne je viditel'ný trend, ktorý pretrvával do roku 2000. ICT trh dosahoval vysoké percentá rastu, ktoré sa pohybovali okolo $12 \%$. V tomto Grafe č.3 je tiež jasne viditel'ná previazanost' trhov, menovite trh USA a Európsky ICT trh. Teroristické útoky na WTC 11.9.2001 ovplyvnili a hlavne ochromili trhy USA, Európy a celý svet. Kým dovtedy dosahovali hodnoty rastu telekomunikačného trhu $14,5 \%$ a IT trhu $12,1 \%$. V roku 2002 to sú hodnoty $2,6 \%$ pre telekomunikácie a trh IT dosahoval po dobu dvoch rokoch záporné hodnoty $-3,4 \%$ a $-1,9 \%$.

Tiež je v Grafe č.3 vidiet' obrat rastu. Kým do roku 2000 rástol rýchlejšie telekomunikačný trh, po úpadku v roku 2001 rastie rýchlejšie trh informačných technológií. A všetko nasvedčuje tomu, že tento trend bude pokračovat'.

V nasledujúcich častiach sú charakterizované, rozčlenené a určené jednotlivé časti jedného z dvoch segmentov trhu, a to IT - trh. 


\section{IT trh}

Trh IT môžeme podl'a EITO rozdelit' na nasledujúce čiastkové trhy:
o IT - služby
o IT - hardware
o IT - software

V d'alšej časti článku si priblížime čast' trhu s IT a to IT- služby.

IT-služby označujú súbor navzájom súvisiacich funkcií alebo služieb, ktoré sú poskytované, IT- systémom alebo IT - oddelením podniku, za účelom podpory obchodnej činnosti podniku. [5]

„Sprievodným znakom rozvoja informačných technológii je nárast dostupných informácií, ktoré je vhodné využit' nielen na proces riadenia, ale najmä na samotnú analýzu údajov a zdokonal'ovanie riadiacej činnosti.“

V užšom slova zmysle IT - služby zahrňujú nasledovné činnosti:
o Outsourcing
o Application Hosting/Application Service Providing
o Facility Management
o Equipment Services
o Maintenance
o Training

\subsection{Outsourcing}

Outsourcing je vyčlenenie riadenia istej činnosti (napr. IS/IT, alebo i marketingových činností) z vlastnej firmy a jeho zabezpečenie externou organizáciou na základe systémovej integrácie. Jeho ciel'om je vyčlenit' také činnosti, ktoré organizácia nezabezpečuje efektívne, pre ktoré nemá potrebné know-how a možno ich efektívnejšie nakupovat' na trhu. Najčastejšie k nim patria obslužné procesy, výskumné, vývojové, l'udské zdroje, prípadne marketingové činnosti. Outsourcing v oblasti IT môžeme rozdelit' na:

- správu hardwaru (servery, PC, tlačiarne, faxy, kopírky, skenery),

- správu firewallov/zabezpečenie Internetu,

- správu siete,

- prevádzku skorého riešenia - dokument manažment,

- správu siet'ových subsystémov.

Outsourcing prináša aj viaceré výhody ako napríklad zníženie operatívnych nákladov, zdiel’anie rizík, finančný zisk, konkurenčné výhody súvisiace so stratégiou podniku.

\subsection{Application Hosting / Application Service Providing}

Application Service Providing (ASP) je progresívna forma outsourcingu. Provider dodáva aplikačné služby ASP prostredníctvom internetovej sieti vel'kým aj malým firmám a jednotlivcom. [4] Užívatel'om prináša tento spôsob predovšetkým úsporu finančných prostriedkov, ktoré by inak museli vynaložit’ na zadováženie softwaru.

\subsection{Facility Management}

Pojem facility management má po celom svete vel’a rôznych definícií. Ale každá vychádza z definície asociácie IFMA: 
„Metóda, ako vorganizáciách zosúladit' pracovné prostredie, pracovníkov a pracovné činnosti. Zahrnuje v sebe princípy obchodnej administratívy, architektúry, humanitných a technických vied. “

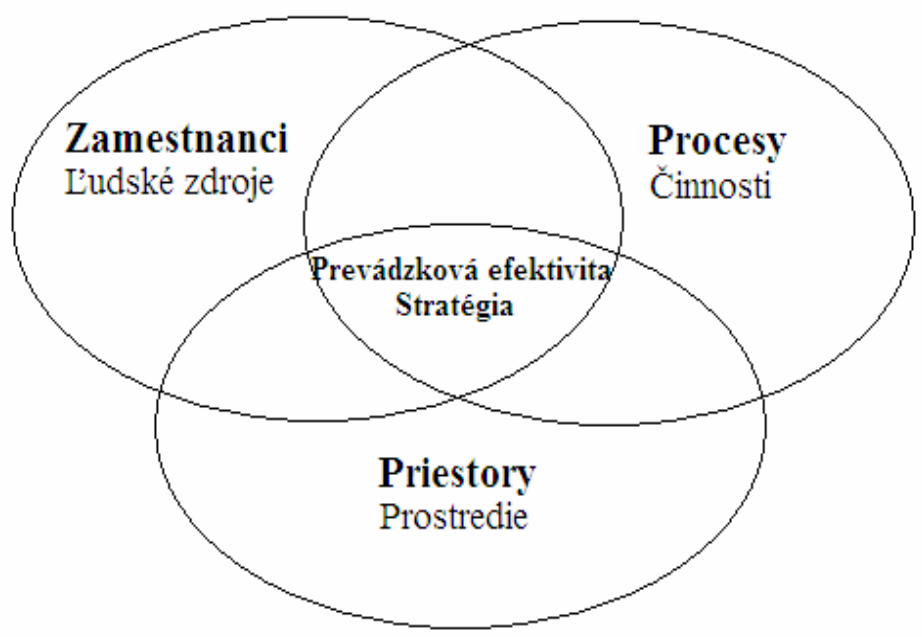

Obr. 1 Štruktúra facility managementu

Táto definícia sa dá vyjadrit' aj graficky (vid' obr. 1). Z tejto schémy je zrejmé, že prvé dve oblasti sú identické vo všetkých manažmentoch. Vždy sa jedná o súbor činností, zabezpečovaných alebo určených pre skupinu osôb. [3] Pre facility management je však špecifická práve tretia oblast', označená ako „Priestory“. Z nej vyplýva aj základný ciel' facility managementu:

Ciel'om je posilnit' tie procesy v organizácii, pomocou ktorých pracovisko a pracovníci podajú najlepšie výkony a vkonečnom dôsledku pozitívne prispejú k ekonomickému rastu a celkovému úspechu organizácie.

Facility management má za úlohu odbremenit’ podnik od množstva zásadných či nevýznamných služieb a to v podobe, ktorá je:

o nákladovo optimálna,

o pre pracovníka najpríjemnejšia,

o legislatívne a formálne regulárna,

o ekologická a energeticky efektívna,

o zodpovedajúca firemným štandardom.

Jednotlivé body tohto prehl'adu sa navzájom vel'mi ovplyvňujú. Jedná sa väčšinou o nepriamu úmeru, čo v praxi znamená, že facility manažér zodpovedný za proces facility managementu musí vediet' vyvážit' jednotlivé zložky tak, aby výsledok bol pre všetky zložky optimálne prijatel'ný. Do konečného efektu je nutné zakalkulovat' aj vel'mi t'ažko finančne vyjadritel'nú položku prirodzene pridanej hodnoty zvýšeného výkonu pracovníka v príjemnom a výkonnost' podporujúcom prostredí. Toto je potom skutočne najvyšším ciel'om facility managementu.

\subsection{Equipment Services}

Equipment Services je činnost', ktorá sa zaoberá službami vybavenia. Zahrňuje inštaláciu, či už hardwarovej alebo softwarovej súčasti IT infraštruktúry, uvedenie do prevádzky, údržbu a demontáž IT vybavenia. 


\subsection{Maintenance}

Pojem „maintenance“ je bežne používaný pojem pre podporu či údržbu systémov, a to nielen v oblasti software. Ide o službu poskytovanú predajcom softwaru alebo hardwaru [1].

Poznáme tieto základné organizačné štruktúry údržby:

o centralizovaná,

o decentralizovaná (zónová, priestorová),

o kombinovaná (čast' centralizovaná a čast' necentralizovaná), ktoré môžu byt'

o interné alebo externé.

Centralizovaná údržba - maintance pracovníci sa zoskupujú do jednoprofesných, alebo viacprofesných skupín a môžu pracovat' kdekol'vek v podniku. Nie sú obmedzení na špecifický priestor. Sú charakterizovaní tým, že chodia pracovat' na prevádzky.

Decentralizovaná údržba - maintance pracovníci sú blízko výrob, v malých dielňach rozdelení po profesiách, sú riadení z jednotlivých výrob prevažne jedným pracovníkom, ktorí organizujú komplexné opravy.

Kombinovaná údržba - čast' údržby je decentralizovaná na prevádzkach a čast' je centrálne riadená.

Externá údržba - je vykonávaná externe dodávatel'skou organizáciou. Tento spôsob údržby je vo výrobných podnikoch ojedinelý. Externá údržba zodpovedá len za vykonanú službu.

\subsection{Training}

Je to $\mathrm{v}$ podstate zabezpečenie vzdelávania pracovníkov za účelom zvýšenia produktivity práce a zabezpečenia vyššej konkurencie schopnosti podniku. Jeho obsahom sú väčšinou môžu sú informačné technológie a tematické okruhy príbuzné tomuto odboru. Training môže mat' niekol'ko podôb napr. klasické školenie, videokonferencia, e-learning.

\section{Záver}

Čast' trhu IT - služby je oblast'ou, ktorá má vel'ké možnosti rozvoja a v budúcom období ju v našich podmienkach očakávajú vel'ké zmeny. Vytvára tak priestor pre podnikanie a prílev investícií, s ciel'om rozvoja IT. Sprievodným znakom rozvoja informačných technológií je nárast dostupných informácií, ktoré je vhodné využit' nielen na podporu procesu riadenia, ale najmä na samotnú analýzu údajov a zdokonal'ovanie riadiacej činnosti. Článok je čiastkovým výstupom projektu VEGA 1/2591/05 „Vplyv výberu efektívnej stratégie na riadenie konkurencie schopnosti podniku“, ktorého som zodpovedná riešitel'ka.

\section{Použitá literatúra}

[1] KREMEŇOVÁ, I. - ROSTÁŠOVÁ, M.: Marketing v službách Marketingový informačný systém. EDIS, ŽILINA, 2005. ISBN 80-8070-358-2

[2] Interný materiál Nemeckej pošty, a.s.

[3] Vlastimil K. Vyskočil, Ondřej Štrup - „Podporné procesy a znižovanie režijných nákladov (facility management)“

[4] MADLEŇÁK, R.: Elektronický obchod, EDIS ŽU Žilina, 2004, ISBN 80-8070-192-X

[5] MAJERČÁKOVÁ, M.: Technológia telekomunikácií, 1. vyd. - Žilina : Žilinská univerzita, 2003. - 166 s., AH 10,38, VH 10,86 : obr., tab. - ISBN 80-8070-159-8. 